\title{
Does globalization reduce child labor?
}

\author{
Krisztina Kis-Katos *
}

July 11, 2006

\begin{abstract}
This paper considers the effects of trade liberalization on child labor that arises out of subsistence needs. It argues that favorable income effects are most likely to reduce the need for child labor in the South, even when export goods have a necessity character. However, in very poor economies, aggregate hours of child labor can also increase as a result of more open trade. Although the poorest families are the ones who benefit the most from trade in a Heckscher-Ohlin setting, their income gains might not be high enough to make them withdraw their children from work, while adverse income effects can raise the incidence of child labor among the less poor. The paper provides empirical support for the argument by finding that in a country panel, increases in trade openness are associated with significantly smaller reductions in child labor among the poorest food exporters than among food exporters on average.
\end{abstract}

JEL Classification: J20, D33, F11

Keywords: Child labor, International trade, Income distribution

\section{To be published in Journal of International Trade \& Development}

\footnotetext{
* Institute for Economic Research, Department of International Economics, University of Freiburg, Germany. Contact: krisztina.kis-katos@vwl.uni-freiburg.de. I am grateful to the Volkswagen Foundation for financial support. I would like to thank two anonymous referees, Günther Schulze, Eva Deuchert, and seminar participants at the Freiburg University for comments and helpful suggestions. All remaining errors are mine.
} 


\section{Introduction}

According to recent ILO estimates, every seventh child in the world is working as a child laborer, predominantly in developing countries. ${ }^{1}$ Triggered by the globalization debate of the last years, awareness about child labor increased hugely, both among policy makers and in the public. The link between international trade and child labor is hotly debated in particular. Does globalization increase the incidence of child labor, or conversely, does trade liberalization reduce the amount of children working?

While some of the most influential theoretical analyses (Basu and Van 1998, Baland and Robinson 2000) address child labor in a closed economy setting only, ${ }^{2}$ several studies look at the interactions between trade openness and child labor. These papers can be divided into two main categories: Earlier open economy models treat child labor either as a fully exogenous factor of production (Brown, Deardorff and Stern 1996) or as a "public bad" (Maskus and Holman 1996, Maskus 1997). More recent studies address endogenous child labor supply which is based on human capital investment decisions that are made under binding borrowing constraints (Grote, Basu and Weinhold 1998, Ranjan 2001, Jafarey and Lahiri 2002). These studies show that international trade affects child labor decisions via two main effects: 1 . income effects arise since goods and factor price changes alter real family income, 2 . incentive/substitution effects arise from changes in the present and future wages of a child that change the opportunity costs and returns to education. Although the income effects in these models unambiguously reduce child labor, this reduction can be more than offset by an increase in the opportunity costs of a child's time (because of rising child wages and falling future skill premia). Thus, the effect of trade liberalization on child labor remains mainly an empirical issue.

The empirical evidence on the relationship between trade openness and child labor does not show a unified picture. In a cross-country setting, measures of trade openness and economy-wide child labor are negatively correlated. Crosssectional studies find that more open economies tend to have lower child labor force participation rates, even when other factors, like per capita income, economic structure, or educational quality, are contolled for (Shelburne 2001, Neumayer and de Soysa 2005). Contrastingly, based on a smaller panel of developing 
countries, Cigno, Rosati and Guarcello (2002) do not find a robustly significant association between trade openness and child labor. Edmonds and Pavcnik (2004) argue that the only channel through which the effect of trade openness is transmitted is by raising per capita GDP. ${ }^{3}$

Studies based on microempirical data, which are generally better suited to investigate the relative strengths of income and substitution effects, show that the overall effect of trade liberalization on child labor differs across countries. Edmonds and Pavcnik (2005b) find that the increase in the price of rice in Vietnam caused by trade liberalization reduced significantly child labor through favorable income effects. Contrastingly, Edmonds, Pavcnik and Topalova (2005) conclude that child labor in India decreased less in provinces that were stronger exposed to tariff cuts due to their industrial employment structure. Krueger (2004) shows that during a coffee sector boom in Nicaragua, there was a significant increase in child labor among rural, coffee producing households.

The present paper puts forward an additional explanation for why child labor increases as a result of trade liberalization. While previous theoretical studies stressed mainly the trade-off between the favorable income and the unfavorable incentive effects, the present paper points out that within the poorest countries, the real income effects of trade can also raise aggregate child labor. The paper follows Basu and Van (1998) by addressing child labor that arises out of subsistence needs, ${ }^{4}$ and adapting their main framework for a small open developing economy. Within this framework, trade liberalization can both raise or reduce the need for child labor in an individual family. The reaction of individual child labor supply depends on the distributional impacts of trade at the family level. The potential decrease in aggregate child labor is due to the poverty-reducing effect of international trade, both via an increase in average income and a reduction in inequality. ${ }^{5}$ However, an increase in trade openness will fail to reduce child labor in aggregate terms if the economy is extremely poor and gains from trade are not large enough. This possibility arises if trade liberalization moves relatively betteroff families towards subsistence while the favorable income effect reduces child labor by less at the lower end of the income distribution. Nevertheless, the overall policy message remains positive: Income effects of trade can reduce the need for some of the worst forms of child labor, captured in this setting by longest hours of constrained work. 
The empirical evidence presented in this paper supports the potential relevance of this argument. In a country panel over four decades (1960-2000), increases in trade openness were associated with significantly less reduction in child labor within the group of the poorest food exporters than for food exporters on average, after controlling for per capita growth, urbanization, as well as regional and time effects.

The paper will proceed as follows: Section 2 sets up a basic model of a small open economy with endogenously determined child labor. Section 3 derives the comparative static effects of a marginal increase in trade openness on child labor outcomes for an individual family and the economy. Section 4 offers empirical support to the main theoretical argument, while Section 5 concludes.

\section{The model}

Production and prices Consider a small open economy of Heckscher-Ohlin type that produces two goods, food $X_{1}$ and a composite manufacturing good $X_{2}$. The manufacturing good is taken as numéraire and the relative price is given by $p$. Production relies on two intersectorally mobile factors, labor $L$ and composite (human and physical) capital $K$, that are fully owned by the domestic households. All markets are perfectly competitive and hence both factors are fully employed. The resulting zero profit and full employment conditions can be written as:

$$
\begin{aligned}
a_{L 1} w+a_{K 1} r & =p & a_{L 2} w+a_{K 2} r & =1 \\
a_{L 1} X_{1}+a_{L 2} X_{2} & =L & a_{K 1} X_{1}+a_{K 2} X_{2} & =K
\end{aligned}
$$

where $w$ stands for wages per efficiency unit of labor, $r$ for the returns to capital, and $a_{L i}(w, r), a_{K i}(w, r)[i=1,2]$ are the optimal per unit input coefficients of labor and capital that depend on factor prices.

The country is imperfectly integrated into the world economy; barriers to trade such as tariffs and transportation costs drive a wedge between the domestic relative price $p$ and the world market price $p^{w}$ :

$$
p=\beta p^{w}
$$


By assumption, good 1 (food) is produced more labor intensively. As the home country is relatively more abundant in (unskilled) labor than the rest of the trading world, food is assumed to be the export good of the economy. ${ }^{6}$ Thus, $\beta<1$. As long as both goods are produced (factor endowments stay within the diversification cone), factor prices $w(p)$ and $r(p)$ are determined by the given output prices only.

Factor ownership and household income Assume that there are $N$ households in the economy that are regarded as single decision making units. Household size is normalized to one parent and one child per household. household $i$ is endowed with 1 unit of adult labor and with $k^{i} \in\left(0, k^{\max }\right)$ units of composite capital, both inelastic in supply. Capital distribution in the economy can be described by a density function $g(k)$. Adult income $y_{a}^{i}$ is given as a sum of adult wage and capital income,

$$
y_{a}^{i}=w+r k^{i} .
$$

Children can also contribute to household income as they are assumed to be perfect substitutes to adult labor in production ("substitution axiom" by Basu and Van 1998). Denote the fraction of time that a child of family $i$ spends working by $l^{i}$ where $0 \leq l^{i} \leq 1$. Since children are less productive than adults with the efficiency parameter $\gamma$, if they are working, they earn the income $y_{c}^{i}$ :

$$
y_{c}^{i}=w \gamma l^{i}
$$

Household preferences over consumption and child labor Assume that all households have identical preferences over consumption of food $c_{1}^{i}$ and the manufacturing good $c_{2}^{i}$. In order to emphasize the effects of subsistence needs, a certain amount $s$ of food consumption is considered a necessity. As long as $s$ is not achieved, families consume only food and none of the manufacturing good. Utility of consumption is thus defined in two steps:

$$
U^{i}= \begin{cases}\iota\left(c_{1}^{i}\right) & \text { if } \quad c_{1}^{i} \leq s \quad \text { with } \quad \iota(s)=u_{0}, \quad \iota^{\prime}>0 \\ u_{0}+u\left(c_{1}^{i}-s, c_{2}^{i}\right) & \text { if } \quad c_{1}^{i}>s\end{cases}
$$

The first line of the utility function $U^{i}$ describes a situation where the family lives at or below the poverty line and spends all its resources on food. The second line 
gives the target function of the household living above the subsistence threshold, which is an increasing, strictly concave and homothetic function with two arguments, consumption of additonal food $c_{1}^{i}-s$ and of the second good $c_{2}^{i}$. Child labor is assumed to exist only as long as it is needed to achieve subsistence consumption ("luxury axiom" by Basu and Van 1998). Thus, children are compelled to work only in those families where adults cannot finance the minimum amount of food on their own. ${ }^{7}$

Household decisions and child labor outcomes Consumption decisions arise from households maximizing utility (4) subject to the family budget constraint. In families where adult income is higher than the costs of subsistence, $y_{a}^{i}>p s$, utility is maximized subject to the adult budget constraint $y_{a}^{i}=p c_{1}^{i}+c_{2}^{i}$. With homothetic preferences, these families spend constant fractions of adult income on both additional amounts of food $c_{1}^{i}-s$ and the composite manufacturing good $c_{2}^{i}$. In families in which adult income falls short of the subsistence costs, an income gap ps $-y_{a}^{i}$ arises. By the "luxury axiom", children work only to the extent needed to close this income gap:

$$
0 \leq y_{c}^{i} \leq p s-y_{a}^{i}
$$

Child income is given by the child wage (eqn. 3b), while child labor in family $i$ is determined by the income gap and child wages:

$$
l_{c}^{i}= \begin{cases}1 & \text { if } \quad y_{a}^{i} \leq p s-w \gamma, \\ \frac{p s-y_{a}^{i}}{w \gamma} & \text { if } \quad p s-w \gamma<y_{a}^{i}<p s \\ 0 & \text { if } \quad p s \leq y_{a}^{i} .\end{cases}
$$

For given goods and factor prices, child labor supply can be represented as a function of family capital $k^{i}$.

\section{- FIGURE 1 ABOUT HERE -}

The two corner solutions pertain to relatively richer families with no child labor, and very poor families that remain below the poverty line even when their children work full-time. A third group of families lives just at the subsistence level and rely 
on some child labor. Denote the fraction of families living below the poverty line by $\eta$ and the fraction of families that reach the subsistence level thanks to child labor by $\theta$. Aggregate capital holdings in these two family types are given by $K_{\eta}=$ $\int_{0}^{k_{s}} k g(k) d k$ and $K_{\theta}=\int_{k_{s}}^{k^{s}} k g(k) d k$. The relevant thresholds of capital endowment $k_{s}$ and $k^{s}$ (c. f. Fig. 1) depend on factor and goods prices in the economy:

$$
\begin{array}{lrl}
k_{s}=\max ((p s-w(1+\gamma)) / r, 0) & \eta=\int_{0}^{k_{s}} g(k) d k \\
k^{s}=\max ((p s-w) / r, 0) & \theta=\int_{k_{s}}^{k^{s}} g(k) d k
\end{array}
$$

With capital endowment of $k_{s}$, a family is just able to finance subsistence consumption when children work full time; with capital endowment of $k^{s}$, adult income just covers the costs of subsistence and no child labor is necessary.

Aggregate child labor supply and goods and factor market equilibria Aggregate hours of child labor supply $L_{C}$ are given by the sum of individual households' child labor supplies:

$$
L_{C}=L_{C \eta}+L_{C \theta}=\eta N+\frac{p S_{\theta}-Y_{A \theta}}{w \gamma}
$$

$L_{C \eta}$ gives total hours of labor by children who work full time; $L_{C \theta}$ aggregates interior child labor outcomes where child income $Y_{C \theta}=w \gamma L_{C \theta}$ is just covering the aggregate "income gap", $p S_{\theta}-Y_{A \theta} \cdot{ }^{8}$ Since markets clear perfectly, factor employment equals aggregate factor supply measured in efficiency units, i.e. $L=N+\gamma L_{C}$. The resulting domestic income is given by $Y=w L+r K=p X_{1}+X_{2}$. The balanced trade equilibrium of the economy is described by setting the value of export supply equal to import demand at world market prices. In equilibrium, the given world market prices and market frictions determine domestic prices. Together with the production technologies and factor endowments they determine factor rewards $w, r$ and hence family incomes, consumption and production patterns, as well as $L_{C}$, the level of child labor in the economy.

\section{Trade liberalization and child labor}

In the policy discussion, greater openness to trade is seen both as one of the causes of child labor problems world-wide and as a potential cure for them. Globalization 
critics often blame international trade for setting new incentives for child labor abuse in the South. In contrast, many economists believe that gains from trade can make a powerful contribution to eradicating child labor. However, while the average income effect always reduces child labor, reductions in inequality in the South can also raise child labor (c.f. Rogers and Swinnerton 2001).

\subsection{Impact of trade on goods and factor prices}

Trade liberalization brings domestic relative prices $p$ closer to the world market prices $p^{w}$. In terms of the present model, $\beta$ rises (hats denote percentage changes):

$$
\widehat{p}=\widehat{\beta}>0,
$$

and hence food becomes relatively more expensive, which raises the costs of subsistence. At the same time factor prices also adjust, wages rise in terms of both goods, while capital returns fall in absolute value (Stolper and Samuelson 1941):

$$
\widehat{r}<0<\widehat{p}<\widehat{w} .
$$

For any given level of child labor, the distributional impacts of these price changes are well-known: Despite the rise in subsistence costs, the poorest benefit from a trade opening as wage increases more than compensate them for a rise in the price of food. Relatively richer families experience a relatively smaller real income gain or even a loss of real income as their capital income diminishes. As a result, income inequality in the economy is unambiguously reduced. The changes in the "income gap" trigger a child labor supply response, individual child labor decisions adapt and hence economy-wide child labor changes. ${ }^{9}$

\subsection{The reaction of individual child labor supply}

The impact of trade liberalization on child labor depends on the changes in adult and child income relative to the rise in the relative price of food. In families where children work some but not all the time, the reactions of child labor supply $l_{c}^{i}$ can be divided into three parts:

$$
\widehat{l_{c}^{i}}=\frac{p s}{y_{c}^{i}} \widehat{p}-\left(\frac{w}{y_{c}^{i}} \widehat{w}+\frac{r k^{i}}{y_{c}^{i}} \widehat{r}\right)-\widehat{w} .
$$


First, there is an adverse price effect that reduces real family income as it makes food relatively more expensive. Second, there is an adult income effect (within the brackets) that can take both signs depending on factor endowments of the family and the relative magnitudes of factor price changes. The larger the share of wage income for total adult income, the more favorable are the adult income effects. Third, there is a child income effect that unambiguously reduces child labor supply. The overall real income effect is clearly favorable for the poorest families as they experience the real gains from a wage increase but remain mainly unaffected by the falling returns to capital. Child labor supply in these families decreases. Families that have more substantial capital holdings adjust their supply of child labor upward or downward depending on the overall sign of the real income effect.

\subsection{Change in economy-wide child labor supply}

Changes in economy-wide child labor depend on the distribution of the income effects to individual families living at or near to the subsistence threshold. With a price change, aggregate hours of child work (7) change for two reasons: as a result of the accumulated changes in individual child labor supply among those families where child labor is interior, and due to changes in the number of children working full time and those working at all. In the present model, marginal changes of the number of child laborers have no first order effects on aggregate child labor (i.e. $\mathrm{d} L_{C}=\mathrm{d} L_{C \theta}$, see Appendix A). Thus, the relative change in aggregate hours of child work is determined as:

$$
\widehat{L}_{C}=\frac{p S_{\theta}}{Y_{C}} \widehat{p}-\left(\frac{w \theta N}{Y_{C}} \widehat{w}+\frac{r K_{\theta}}{Y_{C}} \widehat{r}\right)-\widehat{w} .
$$

which is the economy-wide equivalent of expression (9). Under the assumption of perfect competition, factor price movements depend on the change in goods prices $\widehat{p}$. The change in child labor supply (10a) can thus be reformulated in terms of the relative price change (using the magnification effects of Jones (1965), see Appendix A):

$$
\widehat{L_{C}}=-\frac{1}{\delta} \frac{1}{Y_{C}} w\left(\theta N+\gamma L_{C \theta}-a_{L 1} S_{\theta}\right) \widehat{p}
$$

Child labor supply reactions depend on two main factors: 1 . on the production structure, captured by the difference in unit cost shares between industries, $\delta(>$ 
0 ), and by the unit input coefficient $a_{L 1}$, and 2 . on the importance of subsistence consumption relative to family endowments. Child labor decreases only if the labor supply of those living at the poverty line $\theta N+\gamma L_{C \theta}$ is greater than the labor embodied in their subsistence consumption $a_{L 1} S_{\theta}$. If no families are living under the poverty line, $\eta=0$ and $L_{C \theta}=L_{C}$, the income effect of more open trade unambiguously leads to a decrease child labor (c.f. Appendix A). Intuitively, if there are no families in which children would work maximum hours, income gains to the poorest are directly translated into reductions in child labor supply among them. As average income in the economy increases because of the gains from trade, aggregate hours of child work cannot increase, irrespectively of the increases in child labor supply among the less poor. However, if some parts of the population live below the poverty line, $\eta>0$, there might be situations where the favorable income effects of trade are overturned by the real income losses to the relatively less poor. Such outcomes can arise if despite their real income gains, the poorest still have to send their children to work full-time as they still cannot reach subsistence, while relatively richer families are constrained to rely on more child labor because of their income losses. ${ }^{10}$

Aggregate hours of child work can increase if: 1 . the redistribution of income induced by trade liberalization raises child labor incidence, and 2. the income gains from trade are not large enough to overweigh these effects. A sufficient condition for such an outcome is given in an economy where: 1. large numbers of families live below the poverty line, while there are relatively fewer families with intermediate levels of child labor, i.e., the economy is very poor and the income distribution is strongly skewed to the left; 2 . the comparative advantage in the labor intensive good is relatively small and hence preferable factor price adjusments will be less strong (c.f. Appendix A).

\section{Empirical evidence}

The main empirical implication of the above arguments is that within exporters of subsistence goods such as food, trade liberalization can be expected to reduce the need for child labor, although not everywhere alike. The sufficient conditions for an adverse income effect of trade on child labor predicted by the model are more 
likely present within very poor economies. Other things being equal, the effect of trade liberalization on child labor participation rates should be less favorable in poorer countries where child labor is needed for subsistence of a large share of families. Thus, if the theoretical argument is empirically relevant, one should find that, after controlling for changes in average income, increases in trade openness reduce child labor in countries that are exporters of subsistence goods, but this effect is smaller (or even of opposite sign) for the poorest among them. ${ }^{11}$

\subsection{Data and variables}

To address this question, a panel of 91 developing and industrialized countries is used, where most variables are measured each decade between 1960 and 2000 . Unlike in other empirical studies, the main focus of the regressions is not on the determinants of child labor per se but on the differential impacts of changes in trade openness on changes in child labor over time. The panel includes only countries that reported positive values of child labor in 1960 and only up to the time when child labor participation rates reach zero. ${ }^{12}$ As a total, the sample consists of 300 observations over four time periods, with an average of 3.3 observations per country. ${ }^{13}$

Most data is taken from the World Development Indicators (World Bank 2004). Basic summary statistics are presented in Table 1 . The dependent variable $\Delta C h l a b$ is based on estimates of the ILO; it gives the percentage point change in labor force participation rates of children aged between 10 and 14 years over a decade. As widely argued, child labor force participation rates present only a crude measure of child labor. Nevertheless, they serve as the best available proxy for the prevalence of child labor in a cross-country setting and are widely used in empirical work. $^{14}$

\section{-TABLE 1 ABOUT HERE-}

The main explanatory variable, $\Delta O p e n$ is defined as the percentage point change in the openness indicator over a decade where openness is measured by the ratio of exports plus imports to GDP. While it measures changes in actual trade flows, this openness indicator captures trade policy only indirectly. Alternatively, some 
regressions use changes in the Openness Index of the Fraser Institute (Gwartney, Lawson and Gartzke 2005), $\Delta$ Fraser, as a more direct measure of trade policy changes. ${ }^{15}$ As a component of its Economic Freedom of the World Index, the Fraser Institute estimates the Freedom to Trade Internationally on a scale between 0 and 10 (which has been rescaled here between 0 and 1). The Index is based on information on tariff barriers (and eventually other regulatory trade barriers), on the difference between the actual and expected size of the trade sector, on black market premia, and on international capital market controls.

Between 1960 and 2000 there was a general increase in trade openness based both on actual trade flows and on broader measures of trade policy, as well as a steady decline in child labor participation rates: Child labor force participation rates (within the sample) declined on average by 3 percentage points per decade while trade openness increased on average by 6 to 7 percentage points.

Additional explanatory variables include the extent of child labor to begin with, GDP growth, urbanization, as well as regional and time controls. The labor force participation rate of children in 1960, Chlab1960, captures relevant scale effects as countries with originally higher child labor incidence can experience greater reductions in child labor. The variable $\triangle G D P$ controls for average income effects by measuring the growth of real per capita GDP over a decade which can be expected to unambiguously reduce child labor. GDP per capita is found to be the most powerful explanatory factor of prevalence of child labor in a cross-section of countries (see e.g., Krueger 1996, Edmonds and Pavcnik 2004). The variable $\Delta U$ rban measures the percentage point change in the share of urban population within a country. Although child laborers in manufacturing receive much of the public attention, child labor is still most prevalent in rural societies (Edmonds and Pavcnik 2005a). Urbanization can be thus expected to reduce child labor. Five regional controls (dummies for East Asia and the Pacific, South Asia, Latin America, North Africa and the Middle East, and Sub-Saharan Africa) have also been added to the regressions; they capture further structural differences between child labor trends across the subcontinents. The time dummies capture general economic trends in the world as reductions in child labor have been significantly larger in the last two decades than in the first two decades.

Based on the predictions of the model, three country groups are treated dif- 
ferently: the poorest countries among food (subsistence good) exporters, other food exporters, and the rest. Two indicator variables are used for this purpose. FoodExp $p_{i}$ indicates countries that were or are large exporters of subsistence goods. The variable takes one if the exports of food and agricultural raw materials made out more than a half of merchandising exports of a given country in at least one of the decades during the period of analysis. ${ }^{16}$ The indicator variable $I_{\text {Group }, i}$ stays for the originally poorest countries within the sample. $I_{\text {Group }, i}$ takes the value of one if the country belongs to the group of countries that were the poorest based on their per capita GDP in 1960, where Group size varies between 15 and 35.

\subsection{Estimation strategy and main results}

The main estimation equation takes the following form (for country $i$, decade $t$ ):

$$
\Delta C h l a b_{i t}=X_{i t}^{\prime} \beta+\gamma f\left(\Delta O p e n_{i t}\right)+\epsilon_{i t}
$$

Elements of the vector $X_{i t}$ include the amount of child labor at the beginning of the first period, Chlab1960 $i$, the growth of GDP per capita per decade, $\Delta G D P_{i t}$, the change in urbanization rates $\Delta U_{r b a n}$, and regional and time controls. In order to analyze whether there is a difference in the effects of trade liberalization across country groups, the changes in openness $\Delta O p e n_{i t}$ have been interacted with the indicator variables $\operatorname{FoodExp}_{i}$ and $I_{\text {Group }, i}:{ }^{17}$

$$
\gamma f\left(\Delta \text { Open }_{i t}\right)=\Delta \operatorname{Open}_{i t}\left(\gamma_{1}+\text { FoodExp }_{i}\left[\gamma_{2}+\gamma_{3} I_{\text {Group }, i}\right]\right)
$$

The estimations have been carried out using a generalized linear model for panel data (GEE) (Liang and Zeger 1986) where the correlation structure of the error terms has been explicitly estimated. The main strength of the estimator is that it does not make the assumption of uncorrelated error terms within a group, and hence it can account for the fact that improvements in child labor conditions in a country are correlated over time.

\section{-TABLE 2 ABOUT HERE-}

Tables 2 and 3 show the main regression results. Everything else equal, child labor force participation rates decreased by more in countries with higher child 
labor prevalence. On average, a 10 percentage point increase in GDP growth over a decade led to a further reduction in child labor by 0.14 percentage points. Child labor decreased also by more in countries with larger increases in urbanization. As compared to countries of Europe, Central Asia and North-America, decreases in child labor have been somewhat smaller in Latin America and South Asia, and considerably smaller in Sub-Saharan Africa.

Changes in openness had no additional impact on child labor on average [column (2), Table 2]. However, the effects of opennes differ between country groups: the fifteen poorest exporters of subsistence goods (for which the product of the indicator variables $I_{15} \times$ FoodExp equals one) experienced significantly smaller reductions in child labor [column (4), Table 2] than the average.

\section{-TABLE 3 ABOUT HERE-}

The results of column (4) are replicated in Table 3 for differing Group sizes of the poorest countries, and the total effect for each of the three country types (average, subsistence exporters, poor subsistence exporters) is also reported. The estimated coefficient in row (a) ( $\widehat{\gamma_{1}}$ of eqn. (12)) captures the average impact of an increase in trade openness for all countries. As before, on average, there is no significant relationship between changes in child labor and in openness. However, the estimated effect for an average food exporter $(\mathrm{a})+(\mathrm{b})\left(\widehat{\gamma_{1}}+\widehat{\gamma_{2}}\right.$ of eqn. (12)) is negative; as to be expected, trade liberalization is associated with reductions in child labor for exporters of subsistence goods. Most interestingly, increases in openness are associated with smaller reductions in child labor within the poorest subsistence good exporters. The differential effect for the poorest food exporters as compared to all food exporters ( $\widehat{\gamma_{3}}$ of eqn. (12)) is significantly positive, while the overall effect $(\mathrm{a})+(\mathrm{b})+(\mathrm{c})\left(\widehat{\gamma_{1}}+\widehat{\gamma_{2}}+\widehat{\gamma_{3}}\right)$ is positive although not statistically significant. The differential effect vanishes gradually when the size of the group of the poorest is enlarged. At the same time, the fit of the model clearly deteriorates when group size is increased (see Table 3) which also indicates that the effect is most relevant for the poorest countries. 


\subsection{Robustness of the results}

The results remain broadly the same when trade liberalization is measured not by actual trade flows but by the policy-based Fraser Index $\Delta$ Fraser which proxies changing trade policies (see Tables 4 and 5).

\section{-TABLE 4 ABOUT HERE-}

The use of the Fraser Index of trade openness restricts sample size to 66 countries and makes the sample more biased towards more well-off countries. This might be one of the reasons why the explanatory power of the regressions significantly decreases when using $\Delta$ Fraser instead of $\Delta$ Open. GDP growth and changes in urbanization retain their signs but lose significance. Nevertheless, there is still a significant difference between the effects of increasing trade openness for poorest and less poor food exporters; while trade liberalization reduces child labor for food exporters on average, it does not reduce it for the poorest exporters of food (see Table 5).

\section{-TABLE 5 ABOUT HERE-}

A differential effect for the poorest countries also remains when the sample is restricted to a smaller set of countries where the mechanisms described by the model more likely apply. ${ }^{18}$ The sample has been restricted in two ways: 1 . to 68 non-high income countries (according to the definitions of the World Bank) where child labor can be supposed to pose a more relevant problem, and 2. to 46 main food exporters. In both cases, a significant differential effect of trade liberalization within the poorest countries is found when changes in trade are scaled by original levels of child labor. As to be expected, the difference is more pronounced within the sample of food exporters where the hypothesized income and price effects of trade in subsistence goods most likely apply.

One should bear in mind that these empirical results do not yield to a strictly causal interpretation. If changes in openness and changes in child labor both merely reflect underlying shifts in the general economic environment, openness will not be exogenous to child labor. Unfortunately, there are no good instruments that would predict changes in trade policy. ${ }^{19}$ However, there are no a priori reasons 
to expect the general policy environment to influence both child labor and trade policies differently within the poorest food exporters only. Thus, the patterns found here can be considered at least as indicative.

\section{Conclusion}

The paper investigated potential impacts of international trade on child labor that is motivated by subsistence needs. For this purpose, goods and factor price adjusments have been examined under the additional assumption that the Southern exportable is a necessity. It has been argued that the poorest worker families will benefit the most and the capital-rich families benefit the least or even lose from more open trade. Hence, income effects of trade can be expected to reduce child labor incidence in general. However, reduction in child labor cannot be expected to be uniform across the households. In very poor worker families children might have to work full time despite the favorable income effects while in capital-richer families child work can even increase. Among the losers from more trade there might be also families that live near to the poverty line who will be adversely affected by the reduction of returns to their human and physical capital holdings and by the increase in costs of subsistence. On aggregate, child labor can even increase as a result of more open trade, despite the increases in average income.

The analysis concentrated deliberately only on income effects of trade, arguing that they determine the changes in the actual need for child labor in a family. In reality, the supply of child labor responds also to changing economic incentives, and especially to changes in expected net returns to schooling. Even so, income effects retain their importance as long as parents consider child labor as a "bad", or more importantly, as long as poverty puts effective constraints on their decisions. From a policy perspective, child labor that is compelled by poverty has a special role: As long as the child's earnings are needed for subsistence of the family, a policy intervention can only be successful if it raises the current income of the poor (be it by redistribution, credit provision or other means). Thus, the paper complements the existing theoretical literature on child labor in an open economy setting, without questioning the importance of other explanatory factors for child labor besides poverty constraints. Incentive effects can further weaken 
the favorable reactions of child labor supply and hence, the overall effect of trade liberalization can turn out less favorable than described by the model.

The empirical evidence presented in Section 4 shows that the mechanisms of the model can actually play a role in explaining the impact of globalization on child labor: While not significant on average, trade liberalization was associated with smaller reductions in child labor for the poorest food exporters than for all food exporters. The distributional impacts of trade liberalization can serve as one explanation for smaller reductions in the numbers of working children within poorest subsistence good exporters, even though the relevance of other effects (like changing economic incentives) cannot be excluded.

From a policy perspective, the potentially unfavorable reaction of the numbers of working children should be of less concern if the scale of individual child labor matters as well. The overall message of the analysis is thus positive: Although it is not sure that poverty-induced child labor decreases on aggregate, the need for the worst forms of child labor (captured here by longest hours worked) will be reduced in first place. Especially, the above arguments should not serve to legitimate the imposition of trade sanctions by Northern countries in order to combat child labor. Trade sanctions are completely counterproductive as they reduce the real income of the poorest worker households and harm those families that most likely have to rely on child labor in order to survive.

\section{A Mathematical Appendix}

Proof of $\mathbf{d} L_{C}=\mathbf{d} L_{C \theta}$ : Differentiate (7) totally and get

$$
\mathrm{d} L_{C}=\mathrm{d} \eta N+\frac{1}{w \gamma}\left[S_{\theta} \mathrm{d} p+p \mathrm{~d} S_{\theta}-\mathrm{d} Y_{A \theta}-\gamma L_{C \theta} \mathrm{d} w\right]
$$

Substitute for $d \eta=g\left(k_{s}\right) d k_{s}$ and $d \theta=g\left(k^{s}\right) d k^{s}-g\left(k_{s}\right) d k_{s}$ by noticing that $\mathrm{d} S_{\theta}=$ $N s \mathrm{~d} \theta, \mathrm{d} Y_{A \theta}=\left[N w+r d K_{\theta}\right] \mathrm{d} \theta+\theta N \mathrm{~d} w+K_{\theta} \mathrm{d} r$, and $d K_{\theta}=N\left[k^{s} g\left(k^{s}\right) d k^{s}-\right.$ $k_{s} g\left(k_{s}\right) d k_{s}$. It follows that

$$
\begin{aligned}
p \mathrm{~d} S_{\theta}-\mathrm{d} Y_{A \theta}= & N\{\underbrace{\left(p s-w-r k^{s}\right)}_{=0} g\left(k^{s}\right) d k^{s}-\underbrace{\left(p s-w-r k_{s}\right]}_{=w \gamma} g\left(k_{s}\right) d k_{s}\} \\
& -\theta N \mathrm{~d} w-K_{\theta} \mathrm{d} r
\end{aligned}
$$


and hence,

$$
\mathrm{d} L_{C}=\frac{1}{w \gamma}\left[S_{\theta} \mathrm{d} p-K_{\theta} \mathrm{d} r-\frac{p S_{\theta}-r K_{\theta}}{w} \mathrm{~d} w\right]=d L_{C \theta} .
$$

Relative changes in aggregate child labor (10): Equation (10a) follows from totally differentiating (7). It can be further rewritten by using the magnification effects of Jones (1965), which can be derived by totally differentiating the zero profit conditions (1) and noting that unit input coefficients minimize unit costs: $\widehat{w}=\frac{r a_{K 2}}{\delta} \widehat{p}$ and $\widehat{r}=-\frac{w a_{L 2}}{\delta} \widehat{p}$, where $\delta=\delta_{K 2}-\delta_{K 1}=\delta_{L 1}-\delta_{L 2}$, while $\delta_{L i}=\frac{w a_{L i}}{p_{i}}$, and $\delta_{K i}=\frac{r a_{K i}}{p_{i}}$ (c.f. Wong 1995). Accordingly, (10a) becomes:

$$
\begin{aligned}
\widehat{L_{C}} & =\frac{1}{\delta} \frac{1}{Y_{C}} r\left(K_{\theta}-a_{K 1} S_{\theta}\right) \widehat{p} \\
& =-\frac{1}{\delta} \frac{1}{Y_{C}} w\left(\theta N+\gamma L_{C \theta}-a_{L 1} S_{\theta}\right) \widehat{p}
\end{aligned}
$$

The two expressions are equivalent as child income serves to close the "income gap", $r K_{\theta}=p S_{\theta}-w\left(\theta N+\gamma L_{C \theta}\right)$, and the zero profit conditions apply, $r a_{K 1}=$ $p-w a_{L 1}$.

Child labor supply response if $\eta=0$ : If no families live below the poverty line, $\eta=0$ and $L_{C \theta}=L_{C}$. Since the relatively labor intensive subsistence good is exported $\left(X_{1}>s N\right)$, it holds that

$$
N+\frac{\gamma}{\theta} L_{C \theta} \geq L=a_{L 1} X_{1}+a_{L 2} X_{2}>a_{L 1} s N .
$$

The relationship on the LHS follows as average hours of child work among the poor families are higher as within the whole population $\left(\frac{L_{C \theta}}{\theta N}>\frac{L_{C \theta}}{N}\right)$ Hence, $\theta N+\gamma L_{C \theta}>a_{L 1} S_{\theta}$.

Sufficient conditions for an increase in aggregate child labor: If $\eta>0$, a sufficient condition for an increase in hours worked by children is given by

$$
N+\frac{\gamma}{\theta} L_{C \theta}<L=a_{L 1} X_{1}+a_{L 2} X_{2}<a_{L 1} s N
$$

The prerequisites for such an outcome are 
1. $\frac{L_{C \theta}}{\theta N}<\frac{L_{C}}{N}$ : average hours of child work among the families where children work some time are lower than average hours of child work within the whole economy.

2. $a_{L 2} X_{2}<a_{L 1}\left(s \eta N-S_{\eta}\right)$ : labor inputs needed to produce the amount of food that is missing for those who live below the poverty line are higher than the labor inputs used to produce the manufacturing good. This is more likely if the comparative advantage in the labor intensive good is relatively small, and if subsistence poverty is large.

\section{B Statistical Appendix}

Countries in the sample (Nr. of obs. per country): Algeria (4), Argentina (4), Australia (2), Austria (2), Bangladesh (4), Barbados (2), Belgium (2), Belize (2), Benin (4), Bolivia (3), Botswana (4), Brazil (4), Burkina Faso (4), Burundi (4), Cameroon (3), Chad (4), Chile (3), China (3), Colombia (4), Congo, Rep. (4), Costa Rica (4), Cote d'Ivoire (4), Denmark (2), Dominican Republic (4), Ecuador (4), Egypt, Arab Rep. (4), El Salvador (4), Fiji (3), Finland (2), France (2), Gabon (4), Ghana (4), Greece (3), Guatemala (4), Guyana (3), Haiti (4), Honduras (4), Hong Kong, China (3), Hungary (3), Iceland (2), India (4), Indonesia (4), Ireland (3), Israel (2), Italy (4), Jamaica (4), Japan (2), Kenya (4), Korea, Rep. (3), Lesotho (4), Luxembourg (2), Madagascar (4), Malawi (4), Malaysia (4), Malta (3), Mauritania (4), Mexico (4), Morocco (4), Nepal (3), Netherlands (2), Nicaragua (4), Niger (4), Nigeria (4), Oman (3), Pakistan (3), Panama (2), Papua New Guinea (2), Paraguay (4), Peru (4), Philippines (4), Portugal (4), Puerto Rico (2), Rwanda (4), Senegal (4), Sierra Leone (3), South Africa (3), Spain (2), Sri Lanka (4), Sudan (2), Sweden (2), Switzerland (2), Syrian Arab Republic (4), Thailand (4), Togo (4), Trinidad and Tobago (3), United Kingdom (2), United States (2), Uruguay (4), Venezuela, RB (4), Zambia (4), Zimbabwe (2)

\section{ALSO FOLLOWS:}

-TABLE 6 - 


\section{Notes}

${ }^{1}$ About 186 million children, $15.5 \%$ of the world's child population between age 5 and 14 , were estimated to be involved in child labor in year 2000 (ILO 2002).

${ }^{2}$ The closed economy focus restricts the applicability of some of the policy conclusions. The favorable impacts of a ban on child labor (Basu and Van 1998, Baland and Robinson 2000, Krueger and Tjornhom Donohue 2004, Doepke and Zilibotti 2005) hinge on the presence of wage adjustments that result from a restriction of child labor supply. However, in a small open economy factor prices will be largely determined through international trade at the world market, and hence the room for factor price movements is severely limited. Under these conditions, a direct ban on child labor can turn out harmful for the poor and is bound to encounter enforcement problems (Dixit 2000).

${ }^{3}$ To resolve potential endogeneity problems, they construct a measure of trade openness that is based on economic geography only (following Frankel and Rose 2002). However, the applicability of their results is limited as a measure of geographic openness, although exogenous to child labor, is unable to capture the effects of trade liberalization itself.

${ }^{4}$ Although the complexity of causes for child labor-resulting from an interaction between the education-work trade-off, market imperfections, social norms, eventual parental egoism and intra-family bargaining failures-is now widely acknowledged, poverty is still regarded as one of its most substantial explanatory factors. See for a review of early empirical studies Grootaert and Kanbur (1995). More recent evidence on the determinants of child labor based on microempirical research is summarized by Brown, Deardorff and Stern (2003) and Bhalotra and Tzannatos (2003).

${ }^{5}$ The role of income inequality has been addressed by Swinnerton and Rogers (1999) and Rogers and Swinnerton (2001) who analyze the potential effects of income redistribution on child labor in a somewhat similar framework in a closed economy setting. This paper incorporates their main insights, but it considers a way of income redistribution that has arguably larger policy relevance: In developing economies international trade can achieve actual redistribution of income while the scope for income redistribution via transfers is very limited.

${ }^{6}$ As food is considered a necessity in this model, at least up to a certain level of consumption, it will only be exported at given relative prices $p$ if the labor-abundant economy is productive enough to provide for domestic consumption, and hence no trade pattern 
reversals occur. This assumption will be made throughout the model.

7 This presumes that for any adult income above the costs of subsistence the marginal disutility of child labor always exceeds the marginal utility of consumption.

${ }^{8}$ The aggregate "income gap" is the difference between aggregate food consumption $S_{\theta}=s \theta N$ and aggregate adult income $Y_{A \theta}=w \theta N+r K_{\theta}$ in those families in which child labor is interior.

9 There will be also a further production effect that arises due to a change in child labor supply, and that alters the economy's production possibilities set. This leads to a reallocation of resources between the sectors via the Rybczynski effect (1955). Since under the assumption of imperfect specialization it has no further impacts on family income, this last production effect will be ignored in the present analysis.

${ }^{10}$ As adult incomes differ only because of capital endowment differences in the model, the distributional impacts of changing factor prices can be interpreted in terms of household poverty. Would one distinguish between worker and capitalist households instead, child labor would increase in poor capitalist households, decrease in poor worker households, while it would not react within the extremely poor worker households. Increases in aggregate child labor would be most likely if a large part of poor capitalist households sent their children to work and increases in child labor among them were not compensated by reductions in child labor among poor worker households. I owe this point to an anonymous referee.

${ }^{11}$ In the model the concept of poverty necessary for adverse child labor response is multidimensional. It requires low productivity, large subsistence poverty with children working full-time, and relatively high poverty among small owners of capital. Although the "group of poorest countries" used in the empirical analysis does not cover all of the above aspects, it can be still expected that such adverse circumstances are more likely present in extremely poor economies.

${ }^{12}$ Countries that did not exist in their present form in 1960 are thus excluded from the analysis as well as countries where information on trade openness has been entirely missing.

${ }^{13}$ The main panel includes 23 countries with 2 , 18 countries with 3 , and 50 countries with 4 observations.

${ }^{14}$ Caution is required when exploiting the time aspect of the data. As in most countries, and especially in developing economies, economic censuses are rare, the ILO relies heav- 
ily on projections (both intra- and extrapolations) for its estimates of economic activity rates (ILO 2000). Thus, the reductions in child labor force participation rates will appear considerably smoother in the data than in the reality. In the paper changes in child labor over ten-year periods are used that are relatively less effected by the issue.

15 The correlation coefficient between $\Delta O p e n$ and $\Delta$ Fraser amounts to 0.33 . The other commonly used measure of trade openness, the Sachs and Warner (1995) opennes indicators, could not be used because within the group of the poorest countries there were too few large switches of trade regime which makes a decomposition of the effects of openness change between poor and less poor impossible.

${ }^{16}$ The categories food and agricultural raw products comprise the commodities of SITC sections 0 (food and live animals), 1 (beverages and tobacco), 2 (crude materials except fuels), and 4 (animal and vegetable oils and fats). From section 2 divisions 27 and 28 (crude fertilizers, minerals, metalliferous ores and scrap) are excluded.

${ }^{17}$ Additionally to that, in a series of regressions (not reported here but available on request) the changes in openness have been interacted with the amount of child labor in 1960, Chlab1960 ${ }_{i}$. This generally increased significance of the results and the fit of the regressions which indicates that the impacts of openness were stronger in countries with originally higher levels of child labor.

${ }^{18}$ The results of these regressions are available from the author on request.

${ }^{19}$ Geographic instruments and the concept of geography based trade openness (see Frankel and Rose 2002) are of no help in this case as they capture openness to trade in an inherently static manner and hence do not help to predict policy changes. 


\section{References}

Baland, J.-M. and Robinson, J. A.: 2000, Is child labor inefficient?, Journal of Political Economy 108(4), 663-679.

Basu, K. and Van, P. H.: 1998, The economics of child labor, American Economic Review 88(3), 412-427.

Bhalotra, S. and Tzannatos, Z.: 2003, Child labor: What have we learnt?, Social Protection Discussion Paper Series 0317, World Bank, Washington D.C.

Brown, D. K., Deardorff, A. V. and Stern, R. M.: 1996, International labor standards and trade: A theoretical analysis, in J. Bhagwati and R. Hudec (eds), Fair Trade and Harmonization: Prerequisites for Free Trade?, Vol. 1. Economic Analysis, Cambridge and London: MIT Press, pp. 227-280.

Brown, D. K., Deardorff, A. V. and Stern, R. M.: 2003, Child labor: Theory, evidence, and policy, in K. Basu, H. Horn, L. Román and J. Shapiro (eds), International Labor Standards: History, Theory, and Policy Options, Blackwell, Malden, Mass.; Oxford and Carlton, Australia, chapter 3, pp. 195-247.

Cigno, A., Rosati, F. C. and Guarcello, L.: 2002, Does globalisation increase child labour?, World Development 30(9), 1579-1589.

Dixit, A. K.: 2000, Comment on 'A transaction cost politics analysis of international child labor standards' (Brown, D. K.), in A. V. Deardorff and R. M. Stern (eds), Social Dimensions of U.S. Trade Policies, University of Michigan Press, Ann Arbor, pp. 267-270.

Doepke, M. and Zilibotti, F.: 2005, The macroeconomics of child labor regulation, American Economic Review 95(5), 1492-1524.

Edmonds, E. V. and Pavcnik, N.: 2004, International trade and child labor: Crosscountry evidence, NBER Working Papers 10317, National Bureau of Economic Research, Cambridge, Mass.

Edmonds, E. V. and Pavcnik, N.: 2005a, Child labor in a global economy, Journal of Economic Perspectives 8(1), 199-220. 
Edmonds, E. V. and Pavcnik, N.: 2005b, The effect of trade liberalization on child labor, Journal of International Economics 65(2), 401-419.

Edmonds, E. V., Pavcnik, N. and Topalova, P.: 2005, Trade liberalization, child labor, and schooling: Evidence from India, mimeo.

Frankel, J. A. and Rose, A. K.: 2002, An estimate of the effect of common currencies on trade and income, Quarterly Journal of Economics. 117(2), 437-466.

Grootaert, C. and Kanbur, R.: 1995, Child labour: An economic perspective, International Labour Review 134(2), 187-203.

Grote, U., Basu, A. and Weinhold, D.: 1998, Child labor and the international policy debate: the education/child labor trade-off and the consequences of trade sanctions, ZEF Discussion Papers on Development Policy 1, Center of Development Research, Bonn.

Gwartney, J. D., Lawson, R. and Gartzke, E.: 2005, Economic Freedom of the World, 2005 Annual Report, Fraser Institute, Vancouver, B.C.

ILO: 2000, Estimates and projections of the economically active population 19502010, Vol. 10 of Sources and Methods: Labour Statistics, International Labour Office, Geneva.

ILO: 2002, Every Child Counts: New Global Estimates on Child Labour, International Labour Office, Geneva.

Jafarey, S. and Lahiri, S.: 2002, Will trade sanctions reduce child labour?, Journal of Development Economics 68(1), 137-156.

Jones, R. W.: 1965, The structure of simple general equilibrium models, Journal of Political Economy 73(6), 557-572.

Krueger, A. B.: 1996, Observations on international labor standards and trade, NBER Working Papers 5632, National Bureau of Economic Research, Cambridge, Mass.

Krueger, D. I.: 2004, Child labor and schooling during a Coffee Sector Boom: Nicaragua 1993-1998, mimeo. 
Krueger, D. and Tjornhom Donohue, J.: 2004, On the distributional consequences of child labor legislation, NBER Working Papers 10347, National Bureau of Economic Research, Cambridge, Mass.

Liang, K.-Y. and Zeger, S. L.: 1986, Longitudinal data analysis using generalized linear models, Biometrika 73(1), 13-22.

Maskus, K. E.: 1997, Should core labour standards be imposed through international trade policy?, Policy Research Working Papers 1817, World Bank, Washington D.C.

Maskus, K. E. and Holman, J. A.: 1996, The economics of child labor standards, Discussion Paper 96/10, Department of Economics, University of Colorado at Boulder, Boulder, CO.

Neumayer, E. and de Soysa, I.: 2005, Trade openness, foreign direct investment and child labor, World Development 33(1), 43-63.

Ranjan, P.: 2001, Credit constraints and the phenomenon of child labor, Journal of Development Economics 64(1), 81-102.

Rogers, C. A. and Swinnerton, K.: 2001, Inequality, productivity, and child labor: Theory and evidence, Working paper, http://www.georgetown.edu/faculty/ rogersc/Papers/Ineq.pdf.

Rybczynski, T. M.: 1955, Factor endowment and relative commodity prices, Economica 22(88), 336-341.

Sachs, J. D. and Warner, A.: 1995, Economic reform and the process of global integration, Brookings Papers on Economic Activity 1995(1), 1-118.

Shelburne, R. C.: 2001, An explanation of the international variation in the prevalence of child labour, The World Economy 24(3), 359-378.

Stolper, W. F. and Samuelson, P. A.: 1941, Protection and real wages, Review of Economic Studies 9(1), 58-73.

Swinnerton, K. A. and Rogers, C. A.: 1999, The economics of child labor: Comment, American Economic Review 89(5), 1382-1385. 
Wong, K.-y.: 1995, International Trade in Goods and Factor Mobility, The MIT Press, Cambridge, Mass.

World Bank: 2004, World Development Indicators, CD-ROM. 


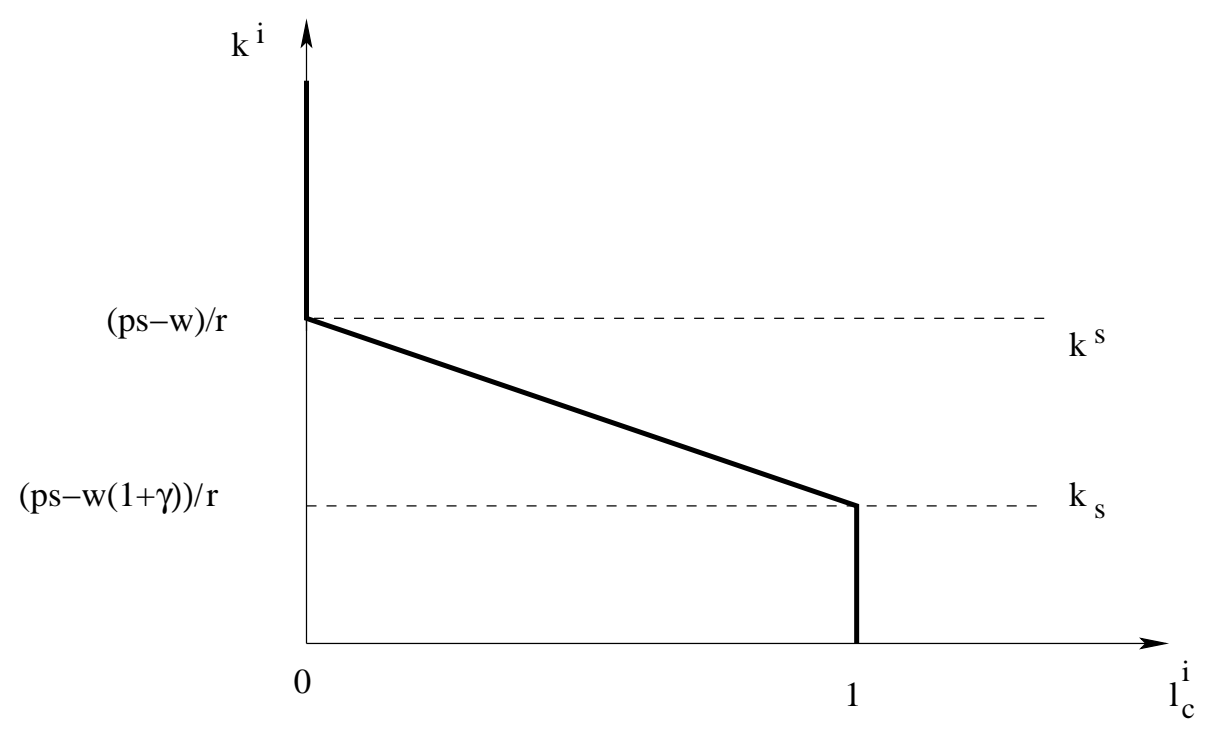

Figure 1: The hours of child labor supply 
Table 1: Summary statistics

\begin{tabular}{l|lrlcc}
\hline Variable & Nr. obs. & Mean & St. dev. & Min. & Max. \\
\hline$\Delta$ Chlab & 300 & -0.030 & 0.025 & -0.152 & 0.059 \\
Chlab1960 & 300 & 0.238 & 0.174 & 0.001 & 0.794 \\
Chlab1970 & 168 & 0.220 & 0.155 & 0.006 & 0.631 \\
$\Delta G D P$ & 300 & 0.172 & 0.259 & -0.841 & 1.050 \\
$\Delta$ Urban & 300 & 0.056 & 0.043 & -0.015 & 0.306 \\
$\Delta$ Open & 300 & 0.070 & 0.187 & -0.550 & 0.939 \\
$\Delta$ Fraser & 168 & 0.062 & 0.121 & -0.330 & 0.420 \\
FoodExp & 300 & 0.547 & 0.499 & 0 & 1 \\
$I_{15}$ (15 poorest) & 300 & 0.180 & 0.385 & 0 & 1 \\
$I_{20}$ (20 poorest) & 300 & 0.247 & 0.432 & 0 & 1 \\
$I_{25}$ (25 poorest) & 300 & 0.300 & 0.459 & 0 & 1 \\
$I_{30}$ (30 poorest) & 300 & 0.360 & 0.481 & 0 & 1 \\
$I_{35}$ (35 poorest) & 300 & 0.417 & 0.494 & 0 & 1 \\
East Asia \& Pac. & 300 & 0.113 & 0.318 & 0 & 1 \\
South Asia & 300 & 0.060 & 0.238 & 0 & 1 \\
Latin America & 300 & 0.293 & 0.456 & 0 & 1 \\
Sub-Sah. Africa & 300 & 0.310 & 0.463 & 0 & 1 \\
North Africa \& ME & 300 & 0.080 & 0.272 & 0 & 1 \\
\hline
\end{tabular}


Table 2: Regression results: Changes in child labor and changes in openness

\begin{tabular}{|c|c|c|c|c|}
\hline & \multicolumn{4}{|c|}{ Dependent variable: $\Delta C h l a b$} \\
\hline & (1) & (2) & (3) & (4) \\
\hline Chlab1960 & $\begin{array}{c}-0.107 \\
(8.66)\end{array}$ & $\begin{array}{c}-0.107 \\
(8.49)\end{array}$ & $\begin{array}{c}-0.107 \\
(8.37)\end{array}$ & $\begin{array}{c}-0.110 \\
(8.08)\end{array}$ \\
\hline$\triangle G D P$ & $\begin{array}{c}-0.014 \\
(2.75)\end{array}$ & $\begin{array}{c}-0.014 \\
(2.65)\end{array}$ & $\begin{array}{c}-0.014 \\
(2.63)\end{array}$ & $\begin{array}{c}-0.014 \\
(2.67)\end{array}$ \\
\hline$\Delta U r b a n$ & $\begin{array}{c}-0.051 \\
(1.77)\end{array}$ & $\begin{array}{c}-0.051 \\
(1.78)\end{array}$ & $\begin{array}{c}-0.051 \\
(1.78)\end{array}$ & $\begin{array}{c}-0.048 \\
(1.64)\end{array}$ \\
\hline$\Delta$ Open & & $\begin{array}{c}-0.005 \\
(0.86)\end{array}$ & $\begin{array}{c}-0.005 \\
(0.79)\end{array}$ & $\begin{array}{c}-0.005 \\
(0.83)\end{array}$ \\
\hline$\Delta$ Open $\times$ FoodExp & & & $\begin{array}{c}0.000 \\
(0.01)\end{array}$ & $\begin{array}{c}-0.004 \\
(0.50)\end{array}$ \\
\hline$\Delta$ Open $\times$ FoodExp $\times I_{15}$ & & & & $\begin{array}{c}0.074 \\
(1.73)\end{array}$ \\
\hline East Asia \& Pac. & $\begin{array}{c}-0.004 \\
(0.90)\end{array}$ & $\begin{array}{c}-0.004 \\
(0.78)\end{array}$ & $\begin{array}{c}-0.004 \\
(0.78)\end{array}$ & $\begin{array}{c}-0.003 \\
(0.71)\end{array}$ \\
\hline South Asia & $\begin{array}{c}0.008 \\
(1.71)\end{array}$ & $\begin{array}{c}0.008 \\
(1.60)\end{array}$ & $\begin{array}{c}0.008 \\
(1.60)\end{array}$ & $\begin{array}{c}0.007 \\
(1.56)\end{array}$ \\
\hline Latin America & $\begin{array}{r}0.007 \\
(2.28)\end{array}$ & $\begin{array}{c}0.007 \\
(2.19)\end{array}$ & $\begin{array}{r}0.007 \\
(2.19)\end{array}$ & $\begin{array}{r}0.007 \\
(2.25)\end{array}$ \\
\hline Sub-Sah. Africa & $\begin{array}{c}0.023 \\
(4.00)\end{array}$ & $\begin{array}{c}0.023 \\
(3.93)\end{array}$ & $\begin{array}{c}0.023 \\
(3.95)\end{array}$ & $\begin{array}{c}0.023 \\
(4.05)\end{array}$ \\
\hline North Africa \& ME & $\begin{array}{c}-0.001 \\
(0.28)\end{array}$ & $\begin{array}{c}-0.001 \\
(0.32)\end{array}$ & $\begin{array}{c}-0.001 \\
(0.32)\end{array}$ & $\begin{array}{c}-0.001 \\
(0.29)\end{array}$ \\
\hline$N$ (Observations) & 300 & 300 & 300 & 300 \\
\hline$n$ (Countries) & 91 & 91 & 91 & 91 \\
\hline Wald-test $\left[\chi^{2}(k)\right]$ & $161.8(11)$ & $154.7(12)$ & $180.1(13)$ & $207.4(14)$ \\
\hline
\end{tabular}

Notes: The models are estimated using the GEE approach where the correlation structure of the error terms is explicitly estimated. Additional controls include time-dummies that are not reported. The reported absolute values of the t-statistics (in parentheses) are based on semi-robust standard errors. Results of Wald-tests of the models are reported, with the degrees of freedom of the $\chi^{2}$ statistics in parentheses. 
Table 3: The differential impact of changes in openness for country groups

Dependent variable: $\Delta C h l a b$
(1)
(2)
(3)
(4)

(5)

\begin{tabular}{lcrrrr} 
(a) $\Delta$ Open & -0.005 & -0.005 & -0.005 & -0.004 & -0.004 \\
& $(0.83)$ & $(0.78)$ & $(0.79)$ & $(0.70)$ & $(0.68)$ \\
(b) $\Delta$ Open $\times$ FoodExp & -0.004 & -0.009 & -0.010 & -0.010 & -0.013 \\
& $(0.50)$ & $(1.04)$ & $(1.16)$ & $(0.89)$ & $(1.05)$ \\
(c) $\Delta$ Open $\times$ FoodExp $\times I_{\text {Group }}$ & 0.074 & 0.048 & 0.045 & 0.019 & 0.021 \\
& $(1.73)$ & $(2.06)$ & $(2.15)$ & $(1.12)$ & $(1.32)$ \\
Estimated $(a)+(b):$ & -0.010 & -0.014 & -0.015 & -0.015 & -0.017 \\
& $(1.29)$ & $(1.88)$ & $(2.07)$ & $(1.46)$ & $(1.60)$ \\
Estimated $(a)+(b)+(c):$ & 0.065 & 0.034 & 0.031 & 0.004 & 0.004 \\
& $(1.47)$ & $(1.47)$ & $(1.45)$ & $(0.30)$ & $(0.31)$ \\
Wald-test $\left[\chi^{2}(14)\right]$ & 207.4 & 193.1 & 193.3 & 183.1 & 185.1 \\
& & & & & \\
\hline Group size & 15 & 20 & 25 & 30 & 35 \\
$N$ (Observations) & 300 & 300 & 300 & 300 & 300 \\
$n$ (Countries) & 91 & 91 & 91 & 91 & 91 \\
\hline
\end{tabular}

Notes: The models are estimated using the GEE approach where the correlation structure of the error terms is allowed to vary over time. The reported absolute values of the tstatistics (in parentheses) are based on semi-robust standard errors. Additional controls include a constant, Chlab1960, $\Delta G D P, \Delta U$ rban, time dummies, and five region dummies (for East Asia and the Pacific, South Asia, Latin America, North Africa and the Middle East, and Sub-Saharan Africa). 
Table 4: Changes in child labor and changes in openness (Alternative openness measure)

\begin{tabular}{lcccc}
\hline & \multicolumn{4}{c}{ Dependent variable: $\Delta C h l a b$} \\
& $(1)$ & $(2)$ & $(3)$ & $(4)$ \\
\hline Chlab1970 & -0.111 & -0.111 & -0.109 & -0.112 \\
$\Delta G D P$ & $(6.91)$ & $(6.91)$ & $(6.79)$ & $(6.96)$ \\
& -0.009 & -0.009 & -0.009 & -0.009 \\
$\Delta$ Urban & $(1.17)$ & $(1.17)$ & $(1.21)$ & $(1.09)$ \\
& -0.062 & -0.062 & -0.067 & -0.069 \\
$\Delta$ Fraser & $(1.29)$ & $(1.27)$ & $(1.37)$ & $(1.40)$ \\
& & 0.000 & 0.010 & 0.010 \\
$\Delta$ Fraser $\times$ FoodExp & & $(0.01)$ & $(0.99)$ & $(0.98)$ \\
& & & -0.031 & -0.038 \\
$\Delta$ Fraser $\times$ FoodExp $\times I_{15}$ & & & $(2.56)$ & $(2.75)$ \\
& & & & 0.038 \\
East Asia \& Pac. & & & & $(1.59)$ \\
South Asia & -0.001 & -0.001 & -0.002 & -0.002 \\
& $(0.21)$ & $(0.21)$ & $(0.25)$ & $(0.25)$ \\
Latin America & 0.017 & 0.017 & 0.017 & 0.017 \\
Sub-Sah. Africa & $(2.07)$ & $(2.05)$ & $(2.18)$ & $(2.17)$ \\
& 0.011 & 0.011 & 0.010 & 0.011 \\
North Africa \& ME & $(1.73)$ & $(1.74)$ & $(1.76)$ & $(1.81)$ \\
& 0.026 & 0.026 & 0.025 & 0.026 \\
$N$ (Observations) & $(3.14)$ & $(3.17)$ & $(3.19)$ & $(3.28)$ \\
$n$ (Countries) & -0.006 & -0.006 & -0.006 & -0.006 \\
Wald-test $\left\{\chi^{2}(k)\right]$ & $(0.68)$ & $(0.68)$ & $(0.71)$ & $(0.75)$ \\
\hline
\end{tabular}

Notes: The models are estimated using the GEE approach where the correlation structure of the error terms is explicitly estimated. Additional controls include time-dummies that are not reported. The reported absolute values of the t-statistics (in parentheses) are based on semi-robust standard errors. Results of Wald-tests of the models are reported, with the degrees of freedom of the $\chi^{2}$ statistics in parentheses. 
Table 5: The differential impact of changes in openness for country groups (Alternative openness measure)

\begin{tabular}{lccccc}
\hline & \multicolumn{5}{c}{ Dependent variable: $\Delta$ Chlab } \\
& $(1)$ & $(2)$ & $(3)$ & $(4)$ & $(5)$ \\
& & & & & \\
(a) $\Delta$ Fraser & 0.010 & 0.010 & 0.010 & 0.011 & 0.011 \\
& $(0.98)$ & $(0.98)$ & $(0.99)$ & $(1.01)$ & $(1.01)$ \\
(b) $\Delta$ Fraser $\times$ FoodExp & -0.038 & -0.038 & -0.036 & -0.035 & -0.035 \\
& $(2.75)$ & $(2.75)$ & $(2.42)$ & $(2.06)$ & $(2.05)$ \\
(c) $\Delta$ Fraser $\times$ FoodExp $\times I_{\text {Group }}$ & 0.038 & 0.038 & 0.019 & 0.009 & 0.009 \\
& $(1.59)$ & $(1.59)$ & $(0.81)$ & $(0.47)$ & $(0.48)$ \\
Estimated $(a)+(b):$ & -0.028 & -0.028 & -0.026 & -0.023 & -0.024 \\
& $(2.54)$ & $(2.54)$ & $(2.12)$ & $(1.80)$ & $(1.80)$ \\
Estimated $(a)+(b)+(c):$ & 0.010 & 0.010 & -0.007 & -0.015 & -0.015 \\
& $(0.47)$ & $(0.47)$ & $(0.36)$ & $(1.16)$ & $(1.16)$ \\
Wald-test $\left[\chi^{2}(13)\right]$ & 149.6 & 149.6 & 136.7 & 139.0 & 140.0 \\
& & & & & \\
\hline Group size & 15 & 20 & 25 & 30 & 35 \\
$N$ (Observations) & 168 & 168 & 168 & 168 & 168 \\
$n$ (Countries) & 66 & 66 & 66 & 66 & 66 \\
\hline
\end{tabular}

Notes: The models are estimated using the GEE approach where the correlation structure of the error terms is allowed to vary over time. The reported absolute values of the $\mathrm{t}-$ statistics (in parentheses) are based on semi-robust standard errors. Additional controls include a constant, Chlab1970, $\Delta G D P, \Delta U$ rban, time dummies, and five region dummies (for East Asia and the Pacific, South Asia, Latin America, North Africa and the Middle East, and Sub-Saharan Africa). 
Table 6: Partial correlation coefficients

\begin{tabular}{l|rrrrrrr}
\hline & $\Delta$ Chlab & Chlab60 & $\Delta$ GDP & AUrban & $\Delta$ Open & FoodExp & $I_{15}$ \\
\hline$\Delta$ Chlab & 1.000 & & & & & & \\
Chlab1960 & -0.476 & 1.000 & & & & & \\
$\Delta$ GDP & -0.076 & -0.259 & 1.000 & & & & \\
$\Delta$ Urban & -0.129 & 0.007 & 0.140 & 1.000 & & & \\
$\Delta$ Open & -0.056 & -0.048 & 0.212 & -0.021 & 1.000 & & \\
FoodExp & -0.074 & 0.313 & -0.204 & -0.184 & -0.001 & 1.000 & \\
$I_{15}(15$ poorest) & -0.222 & 0.532 & -0.033 & -0.098 & 0.013 & -0.009 & 1.000 \\
\hline
\end{tabular}

Notes: The statistics refer to $N=300$ observations [ $n=91$ countries] in the sample. 